\title{
DESIGN OF MOTOR CONTROL SYSTEM ON THE SOLAR DISTILLATION OF PARABOLIC TYPE TO REDUCE SALINITY LEVELS OF SEA WATER
}

\author{
Pabiban Duma*, Namas Mikael, Therik Johannis W.D. \\ State Polytechnic of Kupang, Indonesia \\ *E-mail: hendromeda@gmail.com
}

\begin{abstract}
The purpose of this research are: 1) designing a motor control system to drive the parabolic type solar distillation by utilizing 2 pieces of time sensor and a light sensor to obtain the more result of seawater distillate into fresh water; 2) To get the results of distillate (freshwater) in the amount/volume from the evaporation results; 3) the final result of this study is a parabolic type product that is controlled by a motor. The place to conduct this research was conducted at the Physics Lab of Kupang State Polytechnic. The research method used in this study is the method of experimental and action (action research). Research material: 1 solar unit of parabolic type; The research tool consists of: Arduino Uno, 1 piece; Limit Switch, 2 piece; Light sensor (LDR), 2 piece; Real Time Clock DS1307, 1 piece; Driver Motor H-Bridge Module, 1 piece; Motor DC (Actuator Linear, stroke $65 \mathrm{~cm}$ ), 1 piece; Power supply $12 \mathrm{~V} 10 \mathrm{~A}$, 1 piece; Switch power, 1 piece; Pushbutton, 2 pieces. The results of this study were obtained in 2 system modes designed, namely automatic solar tracking based on time and automatic solar tracking based on detection by light sensors. The solar tracking system on this system uses an axis horizontal system, namely the parabolic type of solar moves one direction from east to west and vice versa. Automatic solar tracking based on the time in this system, the parabolic direction movement mode is based on the parabolic time moved from east to west in line with the direction of the solar movement designed to switch direction every 15 minutes. The output target produced by this research is to produce a product/model of motor control system to drive the parabolic type solar distillation so that obtained the parabolic focus point of sunlight reflection towards evaporation container so that in the end it produces freshwater distillates.
\end{abstract}

\section{KEY WORDS}

Distillation; parabolic type; salinity; motor control system.

The availability of clean water is a rare item and is a major problem in coastal areas. The supporting of clean water availability in coastal areas of the city, such as the city of Kupang is by consuming water from wells, PDAM/local Water Company and reverses osmosis, which now has spread around the edges of the road. In order to get clean water to meet their daily needs for cooking, drinking water, washing and bathing, the community must pay high costs, (Kupang City Statistical Center Agency, 2013).

The effort that can be made to provide clean water is by utilizing existing water sources, one of them is sea water. Sea water is water that comes from the sea, has a salty taste and has a high salinity. To treat the seawater so that it can be used as drinking water, then need to be conducted by designing a parabolic type solar distillation system model tool so as to reduce the salinity level of seawater to be used as drinking water.

The research results from Duma $P$. et al (2016) known that the average result of distillates is $160,71 \mathrm{ml}$, temperature $90,33^{\circ} \mathrm{C}$ and solar heat intensity $664,52 \mathrm{w} / \mathrm{m}^{2}$. The weaknesses during the implementation of research activities are the presence of weather factors such as cloudy, rain, wind and how to focus the parabolic on the focal plane (heating container) resulting in reduced volume of distillate (fresh water). Although this research has been conducted to distill sea water into fresh water with a volume that is still lacking due to disturbing factors, further research is needed by means of a solar parabolic control system towards sunlight to obtain a larger volume of distillate results. In this follow-up research is conducting research to use a motor and sensor control system as a solar tracker so that 
solar parabolic gets higher solar exposure throughout the working day. So that obtained constant reflection result towards the container of seawater.

In the past research, the results of distillates have been given even though the distillate volume is still small because it is influenced by weather, wind and rain factors, and how to focus on heating containers. Although the tool designed has produced distillate (freshwater) but has not provided maximum results (distillate results are still lacking), this is due to how to focus the solar parabolic on the evaporation container still in manual condition. When using a motor control system and sensors, it is expected that the device will provide distillate results or increase the volume of fresh water.

Based on the description of the background, the problem formulated in this study is: 1) how to design a motor control system to drive a parabolic type of solar distillation to produce sea water distillate into fresh water?; 2) how to design a motor control system to drive parabolic solar distillation to get distillate (fresh water) results. While the purpose of this study are: a) designing motor control systems to drive parabolic solar distillation with 2 automatic solar tracking systems using 2 light sensors and automatic solar tracking based on time (Time Limit Swicth); b) with the design of the control system it is expected to produce sea water distillate into fresh water from the evaporation container; $c$ ) the final result of this study is a parabolic type product which is controlled by an electric motor. The benefits of this study are: a) making this parabolic type solar product to distill sea water into fresh water by utilizing a solar tracking system; b) creating the parabolic solar products to distill seawater into fresh water driven by a motorized control system automatically; c) these products can be used by people who live around the coast by utilizing sea water as fresh water as a quality standard for drinking water.

\section{METHODS OF RESEARCH}

This research is a type of action and experimental research. Action research includes several stages, namely the approach of the tool design, the stage of tool making and stage of tool testing and testing of seawater samples.

The location for conducting this research activity is carried out at the Physics Laboratory, State Polytechnic of Kupang. Adisucipto Penfui Street, Kupang Municipality. East Nusa Tenggara Province.

This research activity lasted for 4 months, This research consists two stages, namely: The preparation stage includes: inventory of materials and equipment; design of parabolic type solar distillation devices; The implementation stage includes: parabolic distillation mechanical work; program making; motor installation; as well as measurement; measurement of solar intensity; measurement of sea water distillation results (distillate results); data collection; data analysis; report/seminar results; and publication.

The type of data in this study consists of primary data and secondary data. Primary data namely data that is directly obtained from the field in the form of results of data measurements from the distillation process result data and other supporting data. Secondary data are the documented stored data and data derived from previous research, from journals and other books.

Data analysis techniques in the study are:

- Measuring the volume of results of distillate (fresh water) in the evaporation container during the research takes place using a motor control system and light sensors starting from 6:00 to 18:00 p.m.;

- Conducting measurement (distillation result) in the parabolic type solar distillation system from 6:00 a.m. to 18:00 p.m.;

- Data processing;

- Conclusion. 


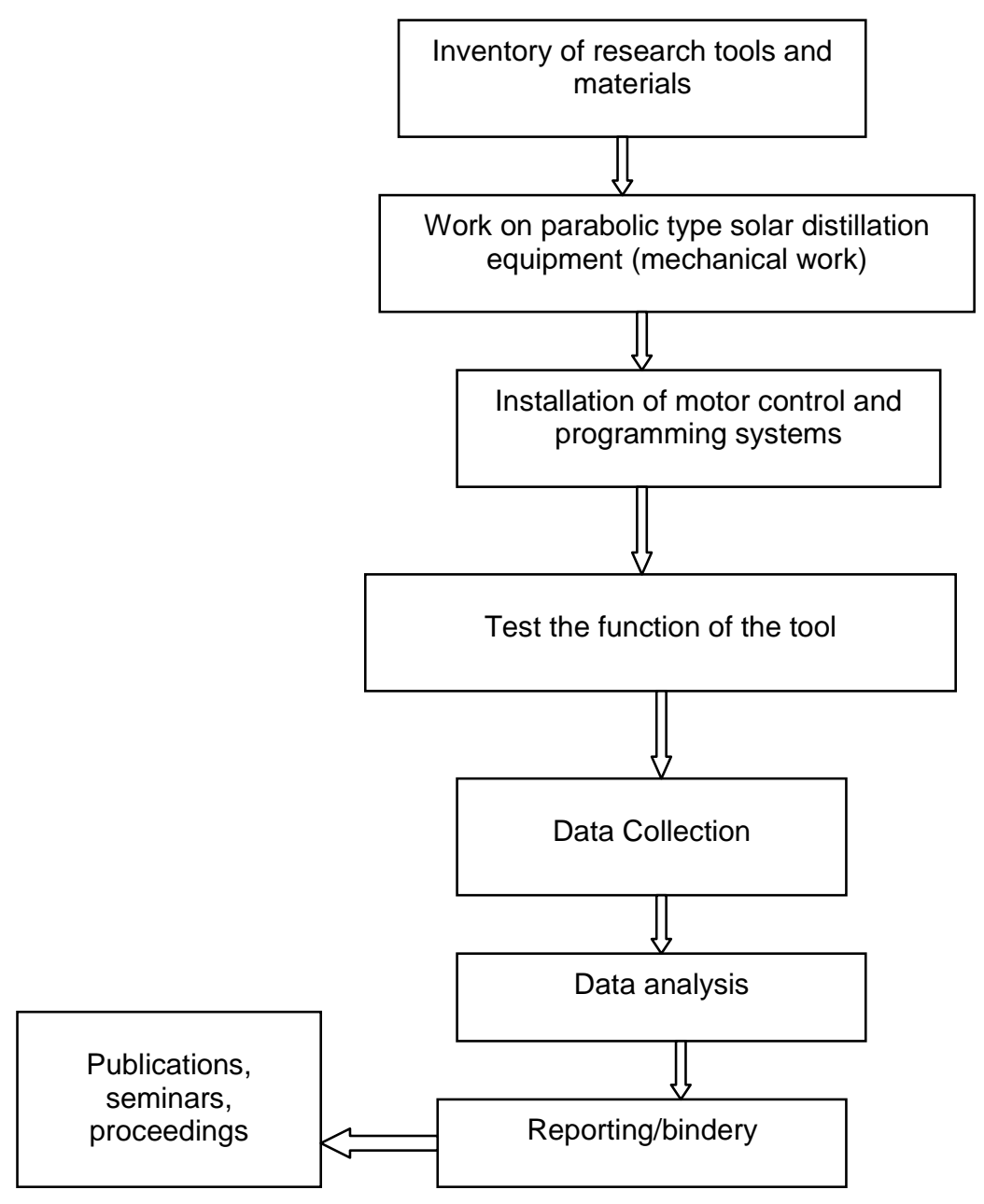

Figure 1 - Research Design

\section{RESULTS AND DISCUSSION}

The implementation of mechanical work begins with the work of welding the iron profile frames as a stand from parabolic type solar distillation. The work on parabolic welding is made in a circle form. Above a parabolic surface, a flat mirror is installed by attaching all the parabolic surfaces evenly; this mirror serves to reflect sunlight towards the evaporation container so that it can accelerate heating in the container. As for the specifications/sizes obtained namely: a) parabolic diameter $1,86 \mathrm{~cm}$; b) height $1,55 \mathrm{~cm}$; c) the maximum volume of the evaporation container up to $2 \mathrm{l}$; d) the parabolic surface area $2,72 \mathrm{~m}^{2}$; e) surface area of the evaporation container $0,0394 \mathrm{~m}^{2}$.

To drive the parabolic type solar distillation is used a linear actuator with the solar tracking system method, on this system using a horizontal axis system that is parabolic solar distillation moves 1 direction from east to west and vice versa. The system designed can work in 2 modes, namely: Tracking the solar automatically based on time; Tracking the solar automatically based on detection by sensors.

The purpose of making these 2 modes, so that the system can still work if one mode is interrupted.

Broadly speaking, the control system components that are used in this system: Arduino Uno, 1 piece; Limit Switch, 2 pieces; Light sensor (LDR), 2 pieces; Real Time Clock DS1307, 1 piece; Driver Motor H-Bridge Module, 1 piece; Motor DC (Actuator Linear, stroke $65 \mathrm{~cm}$ ), 1 piece; Power supply 12 V 10 A, 1 piece; Switch power, 1 piece; Push Button, 2 pieces.

The figure below shows the relationship among the components that build the control system. Details can be seen in Figure 2. 


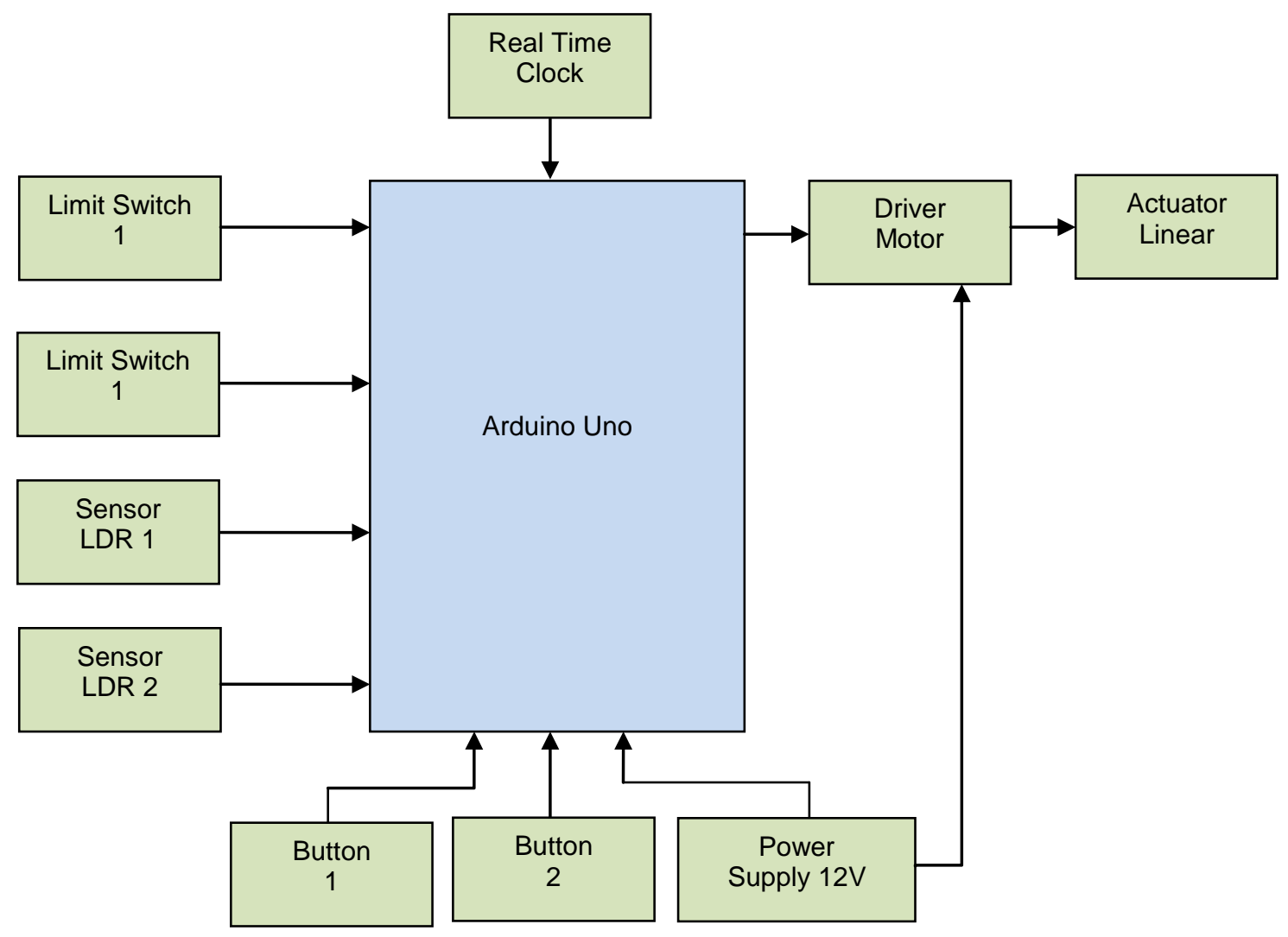

Figure 2 - Block diagram of the Solar Tracking Control System

Description of block diagrams and the circuits:

a. Arduino Uno: An electronic circuit board, with the main component of the ATmega 328 microcontroller chip. Its function here as the brain or processor of the control system.

b. Actuator linear: the output from the system which functions to push or pull down the parabolic face according to the system command. Actuator work after receiving an order from the microcontroller. The working principle of an actuator is to change the motor rotation into a forward (push) and reverse (pull) lever movement in a linear manner.

c. Light Dependent Resistor (LDR): A sensor to measure light intensity,. The sensor function in this system, detects the difference in light intensity, so that when there is a difference in light intensity between the two sensors it will be input for the microcontroller to give commands to change the direction of the parabolic face.

d. Limit switch: Used to border the maximum limit of parabolic movement either to the east or west direction. When the actuator is working conducting push/pull, and the limit switch is pressed, then the system will automatically give an order to the microcontroller to stop the actuator from working.

e. Driver Motor: The driver motor functions to adjust the direction of rotation of the motor rotating towards the left / right. In this case an actuator linear works to push / pull.

f. Real time clock: function for setting the time according to real time, whether the system starts working in the morning until the afternoon.

g. Power supply 12 Volt: as a supply voltage for the control system and actuator linear.

Button 1 and 2: The button here is a button to select the system mode that will run, whether based on time or based on commands from the sensor.

The programming system of motor control system based on time in the form of Algorithms. For Tracking Mode Based on Time, detailed can be seen in Figure 3. 


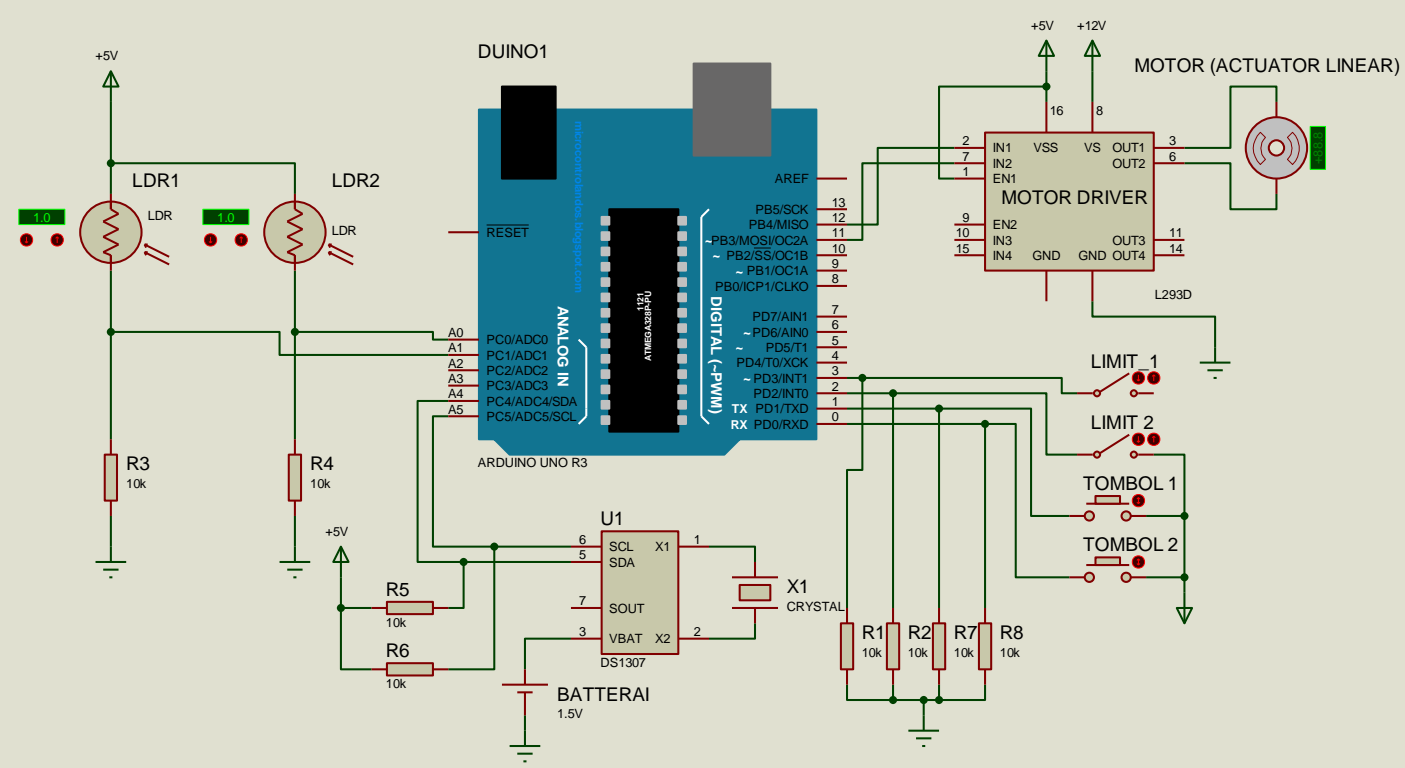

Figure 3 - The Circuit of Solar Tracking Control Systems

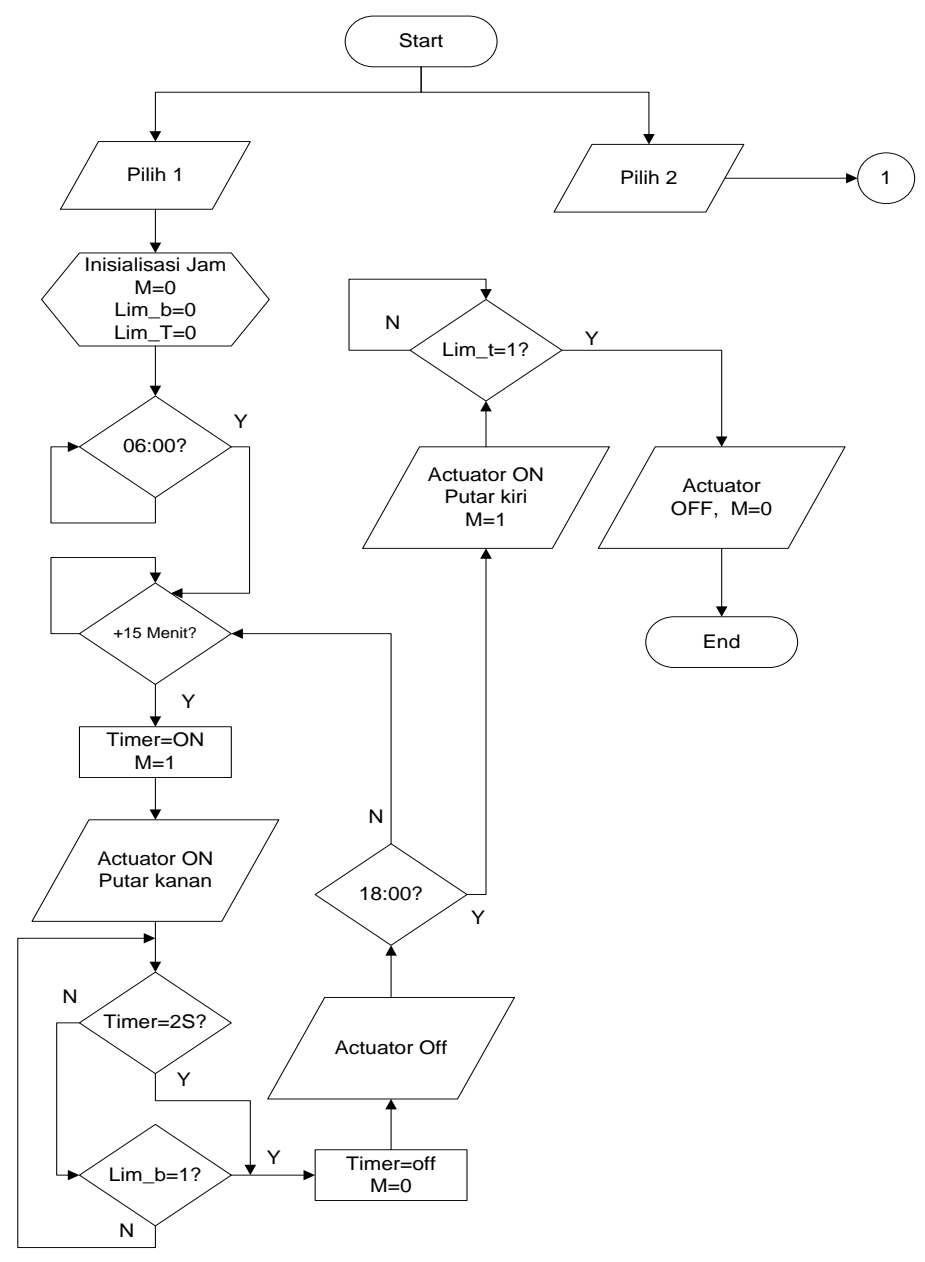

Figure 3 - Algorithm for Tracking Mode Based on Time

By the time the system will be run, first press button 1 or button 2 as a menu to select what system mode will run. 
Principle of the System Working Based On Time Management. in line with the direction of the solar movement. While the degree of movement will be adjusted to the results of the field survey, so that it can be adjusted to how long it takes for the actuator linear to work. In the algorithm above, the researcher gave the time as a sample \pm 2 seconds.

The system will start working automatically at 06:00 AM WITA and stop at 18:00 WITA. When the clock shows at 18:00 WITA, the parabolic direction will automatically move back to the starting position facing east. As a timer on the system, it uses a real-time clock (RTC) from the type of DS1307.

To limit the direction of the parabolic movement, so that it does not exceed the slope limit both east and west, then two limit switches will be installed on the east and west sides, according to the direction of the parabolic movement.

The programming system of the motor control system based algorithm for tracking mode based on sensor more detailed can be seen in figure 4 .

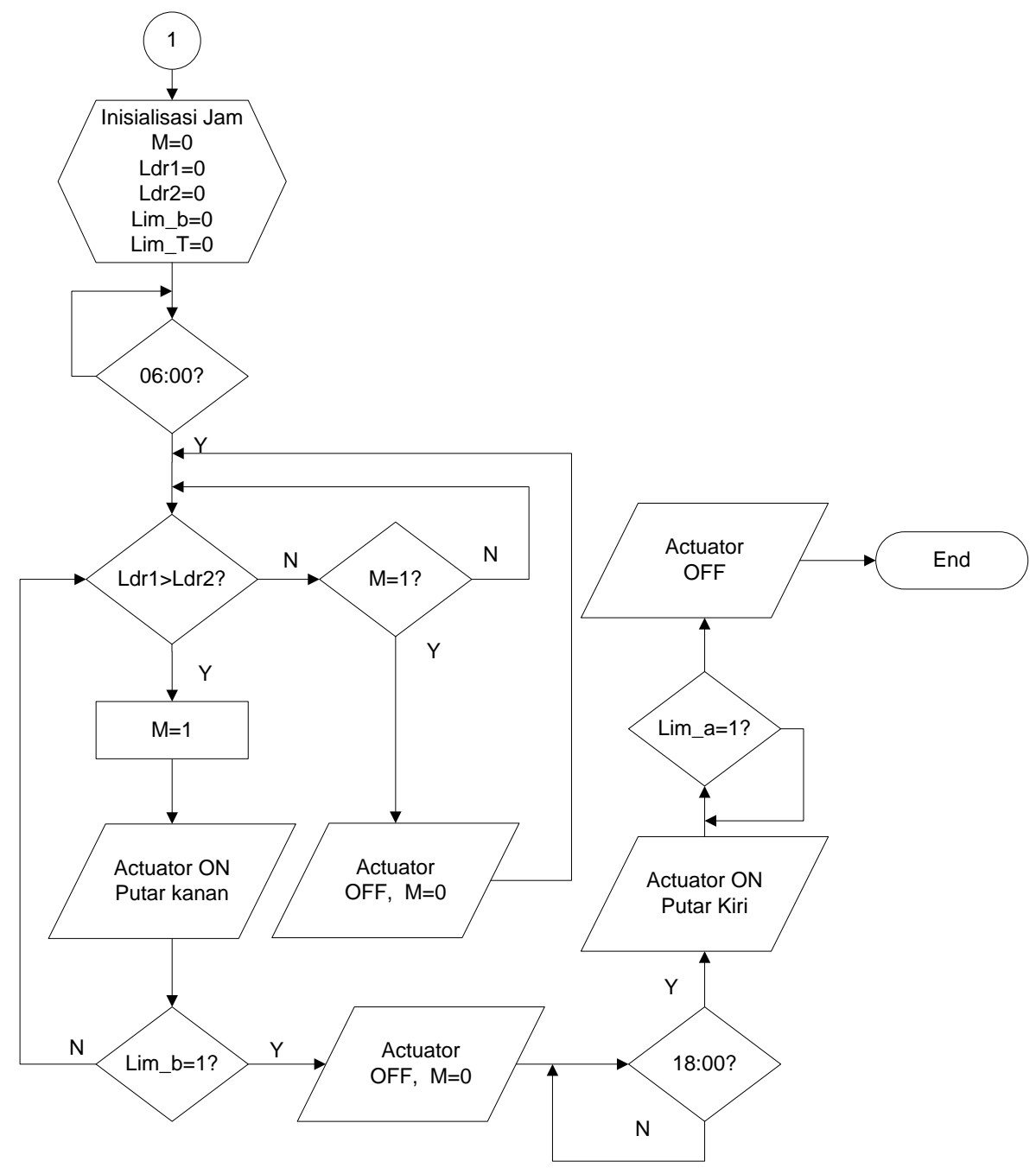

Figure 4 - Algorithms for Tracking Mode Based on Sensors

The working principle of the system based on the searching by sensor. In a system with a parabolic direction movement mode based on searching by a sensor, each of these movements always depends on the sensor. The sensor used is the type of Light Dependent Resistor (LDR) 2 pieces. The sensor will be installed on the east and west side. In accordance with the working principle of the LDR sensor, that the higher the intensity of sunlight the lower the resistance value, so the output voltage of the sensor will also be greater. Based on the LDR principle, the programming algorithm will compare the amount of the output voltage from the two sensors. If the output voltage on Sensor 2 on the west side 
(Ldr_ 2) is greater than Sensor 1 on the east side (Ldr_1), this indicates that sensor 1 has been blocked by the sun. Thus the actuator will work to move the direction of the parabolic face to the west. When the sensor 2 values are smaller or equal to sensor 1 , the actuator linear will stop rotating. The Limit switch function in this system mode is also the same as in time-based mode.

The system will start working when the time shows 06:00 WITA and will stop searching direction of the sun at 18:00 WITA. At 18:00 the system will return the direction of the parabola towards the east and will stand by to work the next day.

The programming language used is $C$ language, while the compiler uses the IDE Arduino. After the program is based on the algorithm in the IDE Arduino, the results of the compiler will be uploaded to the microcontroller on the Arduino Uno board.

\section{CONCLUSION AND SUGGESTIONS}

Based on the results of the discussion in the previous chapter, some conclusions can be drawn as follows:

- To drive the parabolic type solar distillation using solar tracking control system automatically based on time (limit switch), and based on the detection of light by the sensor (LDR / Light Dependent Resistor). The controller of this parabolic type control system is Arduino Uno as an electronic circuit board; with the main component is the ATmega 328 microcontroller chip;

- To limit the direction of the parabolic movement, so that it does not exceed the slope limit either to east and west directions, then 2 pieces limit switch will be installed on the east and west sides, according to the direction of the parabolic movement;

- In a system with a parabolic direction movement mode based on the searching by a sensor, each movement is always dependent on the sensor. The sensor used is the type of Light Dependent Resistor (LDR) 2 pieces. The sensor will be installed on the east and west side. In accordance with the working principle of the LDR sensor, that the higher the intensity of sunlight the lower the resistance value, so the output voltage of the sensor will also be greater;

- Based on the LDR principle, the programming algorithm will compare the amount of output voltage from the two sensors. If the output voltage on Sensor 2 on the west side (Ldr_2) is greater than Sensor 1 on the east side (Ldr_1), this indicates that sensor 1 has been blocked by the sun. Thus the actuator will work to move the direction of the parabolic face to the west. When the sensor 2 values are smaller or equal to sensor 1 , the actuator linear will stop rotating.

After conducting this research, the writer suggests:

- Further research is needed to find out more in detail about the synchronization between the motor and the mechanical workload of the designed parabolic solar distillation system;

- Determination of slope angle at each location will be different; therefore it is recommended that data collection/research should be conducted at different locations.

\section{REFERENCES}

1. Aba, L., 2007, Karakteristik Permukaan Absorber Radiasi Matahari pada Solar Still and Aplikasinya sebagai Alat Distilasi Air Laut menjadi AirTawar, J. Sains MIPA, 13, 201-205.

2. Abdullah, S., 2005, Pemanfaatan Distilator Tenaga Surya (Solar Energy) untuk Memproduksi Air Tawar dari Air Laut, Laporan Penelitian, UGM, Yogyakarta.

3. Afrianto, E. 1991, Teknik Pembuatan Tambak Udang, Kanisius, Yogyakarta.

4. Alamsyah, S., 2007, Merakit Sendiri Alat Penjernih Air untuk Rumah Tangga, PT. Kawan Pustaka, Jakarta.

5. Arief, D., 1984, Pengukuran Salinitas Air Laut and Peranannya dalam IImu Kelautan, jurnal oseana, 9 (1), 3-10. 
6. Arismunandar, W., 1995, Teknologi Rekayasa Surya, PT. Pradnya Paramitha, Jakarta.

7. Astawa, K., 2008, Pengaruh Penggunaan Pipa Kondensat sebagai Heat Recovery pada Basin Tipe Solar Still Terhadap Efisiensi, J. Ilmiah Teknik Mesin Cakram, 2(1), 34-41.

8. Astawa, K., Sucipta, M. and Gede, I., 2011, Analisa Performansi Distilasi Air Laut Tenaga Surya Tipe Prismatik Menggunakan Penyerap Radiasi Surya tipe Bergelombang Berbahan Dasar Beton, Jurnal Ilmiah Teknik Mesin Cakram, 5 (1), 7-13.

9. Aprialdi Pangemenu, 2012 http://pagemenu.blogspot.co.id/

10. Badan Pusat Statistik Indonesia, 2013, Perkembangan Beberapa Indikator Utama SosialEkonomi Indonesia, Badan Pusat Statistik, Jakarta.

11. Badan Pusat Statistik Kota Kupang, 2013, Profil Kesehatan Kota Kupang, Badan Pusat Statistik, Kupang.

12. Budiana, I.G.M.N., 2008, Dasar-Dasar Pemisahan, Universitas Nusa Cendana, Kupang.

13. Catrawedarma, I.G.N.B., 2008, Pengaruh Massa Air Baku terhadap Performansi Sistem Destilasi, Jurnal Ilmiah Teknik Mesin Cakram, 2 (2), 117 - 123.

14. Dahuri, R., Rais, Y., Putra, S.G. and Sitepu, M.J., 2001, Pengelolaan Sumber Daya Wilayah Pesisir and Lautan Secara Terpadu, PT Pradnya Paramita, Jakarta.

15. Hidayat, R.R., 2011, Rancang Bangun Alat Pemisah Garam and Air Tawar dengan Menggunakan Energi Matahari, Skripsi, Institut Pertanian Bogor, Bogor.

16. Irianto, A., 2003, Probiotik Akuakultur, Gadjah Mada University Press, Jogjakarta.

17. Kreith, F., 1991, Prinsip-Prinsip Perpindahan Panas, diterjemahkan oleh Arko Prijono, Erlangga, Jakarta.

18. Lakitan, B., 2002, Dasar-Dasar Klimatologi, PT Raja Grafindo Persada, Jakarta.

19. Larasati, D.A., 2013, Analisis Pengaruh Reduksi Suhu terhadap Efisiensi PhotovoltaicModule, Skripsi, Fakultas Teknik Universitas Jember, Jember.

20. Linsley, R.K. and Franzini, J.B., 1995, Teknik Sumber Daya Air, Erlangga, Jakarta.

21. Meyers, R.A., 1992, Encyclopedia of Physical Science and Technology, 2nd edition Volume 5, Academic press, New York.

22. Muhammad, E.W., 2008, Membuat Kompor Tenaga Matahari, http://www.kamase.org/

23. Mulyanef,Marsal, Arman, R. and Sopian K., 2006, Sistem Distilasi Air Laut Tenaga Surya menggunakan Kolektor Plat Datar dengan Tipe Kaca Penutup Miring, Laporan Penelitian, Fakultas Teknologi Industri,Universitas Bung Hatta, Padang.

24. Nanawi, G., 2001, Kualitas Air and Kegunaannya di Bidang Pertanian, Direktorat Pendidikan Menengah Kejuruan, Jakarta.

25. Pabiban, D.,Namas,M,dan Sarifudin,K. 2016. Model Sistem Distilasi Surya Tipe Parabolic Untuk Menurunkan Kadar Salinitas Air Laut. Laporan Penelitian Hibah Bersaing. Politeknik Negeri Kupang, Kupang.

26. Pabiban, D.,Namas,M,. 2017. Perancangan Sistem Distilasi Surya Tipe Parabolic Untuk Menurunkan Kadar Salinitas Air Laut Sebagai Baku Mutu Air Minum. Laporan Penelitian Rutin Politeknik Negeri Kupang, Kupang.

27. Peraturan Menteri Kesehatan Republik Indonesia Nomor 416/Menkes/Per/IX/1990 Tentang Syarat-Syarat and Pengawasan Kualitas Air Minum, Depkes RI, Jakarta.

28. Peraturan Menteri Kesehatan Republik Indonesia Nomor 492/MENKES/PER/IV/2010 Tentang Persyaratan Kualitas Air Minum, Kementerian Kesehatan Republik Indonesia.

29. Sanropie, D., 1984, Buku Pedoman Study Penyediaan Air Bersih, Akademi Penilik Kesehatan Teknologi Sanitasi, Pusdiknakes Depkes RI, Jakarta.

30. Santosa, I., Wibowo, A. and Wilis, G.R., 2010, Pengaruh Kemiringan Kaca pada Alat BasinSolar Still Terhadap Kapasitas Air Hasil Distilasi, Laporan Penelitian, Fakultas Teknik Universitas Pancasakti, Tegal.

31. Soetrisno, 2004, Teknik Sumber Daya Air, Erlangga, Jakarta.

32. Suhada, H., 1995, Energi Regeneratif sebagai Pilihan Energi Masa Depan, Dimensi vol 20/EMTI.

33. Undang-Undang Republik Indonesia Nomor 7 tahun 2004 Tentang Sumber Daya Air.

34. Wikipedia.com, 2008, Radiasi Surya, Dikutip dari http://www.wikipedia.com, akses tanggal 16 Maret 2014.

35. Wikipedia.org, Intensitas Cahaya, Dikutip dari, akses tanggal 20 Juni 2014. 